\title{
School science for six-year-olds: a neo- vygotskian approach to curriculum analysis
}

\author{
Anya Morris, Joanne Hardman and \\ Heather Jacklin
}

\begin{abstract}
This article examines the forms of knowledge that constitute 'science' in the early school curriculum in South Africa. We examine curriculum excerpts which represent the subject 'science' in key curriculum texts for Grade R, the year in which learners are generally sixyears-old. Drawing on neo-Vygotskian theory, these representations are described in relation to simple scientific concepts, i.e. concepts that are consistent with scientific criteria and function as entry level concepts leading to the acquisition of more complex scientific concepts.

The study found that these key curriculum texts do not represent any science concepts in ways that conform to the criteria for simple scientific concepts. Instead, these texts represent most science knowledge in terms of everyday concepts while a few concepts are introduced in a way that could potentially prompt the Grade $\mathrm{R}$ educator to translate an everyday concept into a simple scientific concept, i.e. as 'potential' scientific concepts. The implications are that the curriculum is not oriented to giving Grade $\mathrm{R}$ learners the opportunity to acquire the form or content of scientific knowledge or to develop the cognitive skills required for formal schooling.
\end{abstract}

\section{Introduction}

South Africa is concerned. Approximately $60 \%$ of children do not complete their schooling (Klinck, 2013) and high school learners are underperforming in science and mathematics (Klinck, 2013; TIMSS, 2011; DBE, 2011d). One of the reasons that children in higher grades are struggling to acquire more 
complex science ${ }^{1}$ concepts may be found in the way science concepts are introduced in the early years of schooling.

There is growing research evidence for the claim that children are able to grasp scientific concepts at an early age and that they benefit from doing so. Young children can think abstractly and are cognitively more competent than was suggested by developmental theorists in the early 1900s (WinklerRhoades, Carey, and Spelke, 2013; Haynes and Murris, 2012; Fleer, 2010; Ginsberg and Golbeck, 2004; Egan, 2002). Neuroscience has confirmed that most of the brain's physical development takes place before they enter formal schooling (Shonkoff and Phillips, 2000). According to the longitudinal High/Scope Perry Preschool Study (2005), quality early education supports academic, personal and social competencies in adulthood.

With regard to science, specifically, Sylva, Melhuish, Sammons, SirajBlatchford and Taggart (2004) argue that learning about science contributes qualitatively to early education and that a limited exposure to science in the early years may create a barrier to the later learning of science (see also Mantzicopoulos, Patrick and Samarapungavan, 2008). As preschool children are more likely to be exposed to mathematics and literacy in the home than to science, many children begin their schooling with a relative deficit in science (Mantzicopoulos, Patrick and Samarapungavan, 2008).

Against this background, the study reported here examined how - if at all scientific concepts are introduced in South African curriculum texts pertaining to Grade R, the year in which learners are six year olds. Our interest is whether this representation is likely to support the later acquisition of more complex scientific concepts.

\section{Theoretical framework}

This study adopts a neo-Vygotskian perspective on early science acquisition. This study therefore is located in the dialectical logic of Vygotsky, rather than

\footnotetext{
We have chosen science as the object of our paper because science integrates knowledge, mathematics, literacy and critical thinking skills. In doing so, we differentiate between 'scientific knowledge', or schooled knowledge, including, for example, history, and 'science' as a discipline or school subject.
} 
in the more traditional binary logic of classic Western theories of development. The neo-Vygotskians comprise a large and diverse group. The ideas employed here are drawn from scholars who focused on early child development and knowledge i.e. Vygotsky's Russian students and followers such as Luria (1976) and Zaporozhets and Elkonin (1971), and Westerners such as Hedegaard (2002) and Fleer (2010). The study drew heavily on Davydov $(1990,2008)$ whose work spans the twentieth and twenty-first centuries.

The ideas of the neo-Vygotskians regarding knowledge and learning can be contrasted to Piagetian informed discovery based approaches that are relatively common in this field of scholarship and implicitly underpin many South African curricular texts (French, 2004; Gelman and Brenneman, 2004; Ginsberg and Golbeck, 2004; Lind, 1998; Skamp, 1998; Doris, 1991). While Piaget's idea of developmental stages is at times interpreted as placing limitations on young children's cognitive competencies, scholars such as Winkler-Rhoades, Carey and Spelke (2013), Haynes and Murris (2012), Fleer (2010), Ginsberg and Golbeck (2004) and Shonkoff and Phillips (2000) argue that learning school knowledge can enhance cognitive development. Davydov views school knowledge as ". . . one of the most significant sources of the school children's psychical development' (2008, p.191) while Sylva, et al. (2004) found that learning science contributes qualitatively to cognitive development in the early years (See also Harrison, 2011; Fleer, 2010; Bodrova and Leong, 2001). This view does not imply that the majority of six-year-olds can think in terms of complex scientific concepts, nor that they are capable of formal operational thinking. However, it does suggest that, in general, six-year-olds can acquire simple scientific concepts.

\section{Simple scientific concepts}

The notion of a simple scientific concept was derived from Vygotsky's distinction between spontaneous concepts based on everyday experience, which we might call everyday knowledge, and scientific knowledge (Vygotsky, 1962 and 1978). Vygotsky viewed these as two opposing but complementary knowledge structures. It is important to note here that the dialectical logic underpinning Vygotsky's work means that spontaneous concepts cannot be viewed outside of scientific concepts and vice versa. An analogy animates this point: when one looks at a piece of string one sees only 
the string, however, the string is made up of fibres. Without the fibres there is no string and without the string the fibres cease to have a meaning. The same is true of scientific and spontaneous concepts. For developmental learning to occur, both concepts are necessary. This distinction has been developed in light of neo-Vygotskian perspectives on school knowledge (Davydov, 1990, 2008; Hedegaard, 2002; Fleer, 2010). From a neo-Vygotskian perspective, everyday knowledge comprises randomly organised isolated ideas that are easily perceived through the senses. Scientific concepts, on the other hand, are units of scientific knowledge which can be distinguished from everyday concepts because they have the following features:

- $\quad$ Scientific concepts are systematically interrelated within hierarchical academic knowledge systems.

- As scientific concepts are positioned within a hierarchical structure, they are mediated by other scientific concepts.

- Scientific concept formation requires higher order thinking and involves abstraction, systemisation and generalisation.

- Scientific concepts are couched in academic language.

- $\quad$ Scientific concepts are generally acquired through schooling (Vygotsky, 1962).

Vygotsky's notion of scientific knowledge was extended by the neo-Vygotskians in the following three ways:

Firstly, each scientific concept constitutes its referent in relation to essential and non-essential attributes. Essential attributes are the primary attributes of an object or phenomenon which uniquely define and distinguish the object or phenomenon from other objects or phenomena (Davydov, 1990). Davydov illustrates this notion with the following example: The two essential attributes of a triangle are three straight sides and three angles. The non-essential attributes would be the colour and size of the triangle. If the essential attributes change then the shape is no longer a triangle; if the non-essential attributes change the triangle still remains a triangle. The notion of essential attributes or properties as essential, inherent, and constant is one of the rules governing a scientific concept. In other words: 


\begin{abstract}
Science strives to advance from the mere description of phenomena to the discovery of the essence of their internal connection. It is well known that essence has a content that is distinct from the immediate given properties of objects or phenomena (Davydov, 2008, p.76).
\end{abstract}

Secondly, a scientific concept is an integral two part structure comprising content and procedural knowledge. 'Scientific knowledge, however, cannot be reduced to the verbal definitions of scientific concepts but should include procedural knowledge relevant to these concepts as well' (Karpov, 2005, p. 182). In the absence of essential attributes content knowledge does not exist, and in the absence of content knowledge procedural knowledge as the related internalising processes does not exist. Procedural knowledge is, in simple terms, knowing how to work with a concept. Davydov explains:

\footnotetext{
Mastering a concept means not only knowing the attributes of the objects and phenomena embraced by the given concept but also being able to apply the concept in practice, being able to operate with it (Davydov, 1990, p.11).
}

In simple terms this means, for example, that six-year-olds can sort a group of diverse shapes into 'triangles' and 'other shapes' by operationalising the two essential attributes of a triangle i.e. 'Does this shape have three straight sides and three angles or corners?'

Thirdly, Vygotsky's notion that scientific concepts are acquired through schooling was developed with regard to the relation between scientific knowledge and schooling as specialised contexts of acquisition. Thus school knowledge is sanctioned, selected knowledge framed by a particular context for the purpose of schooling children (Fleer, 2010; Morais, Neves and Pires, 2004; Hedegaard, 2002; Rogoff, 1990). Within schools, empirical concepts based on experience are restructured as scientific concepts (Hedegaard, 2002). The primary feature that differentiates empirical concepts from scientific concepts is that the former are context-dependent e.g. It snows in winter, whereas scientific concepts are universally applicable and transferable across contexts e.g. the seasonal changes in winter are caused by the earth moving away from the sun.

Within schools there is, ideally, a distribution of knowledge that reflects progression from simple scientific concepts towards more complex concepts. For example, the notion that 'plants require light and water in order to grow' introduces a set of interrelated relatively simple concepts that are positioned at the beginning of the scientific knowledge continuum (plants, light, water, 
grow). These underpin more complex concepts e.g. H20 and photosynthesis, positioned further along the continuum. A highly complex scientific concept e.g. $E=m c 2$ is underpinned by understanding complex concepts such as gravity, mass and speed of light; these concepts are, in turn, underpinned by simpler concepts such as speed, size which, in turn, depend on understanding basic concepts such as heavy and light, fast and slow. Thus simple scientific concepts bridge the young children from the everyday world into the world of science. We note that everyday and scientific concepts are necessarily dialectically linked but for the purpose of this paper we focus our analytical gaze on the scientific concepts.

For purposes of this study, we have drawn on these ideas to develop the following conceptual framework:

1) A simple scientific concept is defined by the following criteria:

- A simple scientific concept has two or more essential attributes

- Although a simple scientific concept is couched in language that is likely to be understood by six-year-olds, simple scientific concepts also employ specialised terms that are universally understood to represent the same thing

- A simple scientific concept is part of an ordered, hierarchical knowledge system within which concepts are systematically interrelated.

- A simple scientific concept is transferable across contexts

2) Each simple scientific concept has two integral parts:

- Content knowledge

- Procedural knowledge i.e. the mental processes and activities related to the acquisition of the content knowledge.

3) A simple scientific concept underpins more complex scientific concepts. 


\section{Methodology}

The study focused on the way science knowledge is represented in the Curriculum and Assessment Policy Statement (CAPS) Grade R Beginning Knowledge texts, which stipulate the science content for six-year-olds in public schools in South Africa. To this end, we analysed selections from three texts: the curriculum statement for Grade R, the workbooks that have been issued nationally to Grade R learners and the CAPS curriculum statements for science for grades one to six.

The data was organised into three categories as follows:

1. Twenty two data segments were selected from the National Curriculum Statement (NCS), Curriculum and Assessment Policy Statement (CAPS) Grade R science study area Beginning Knowledge (DBE, 2011a, pp. 15-21) as the primary data for analysis. The following is an example of a primary data segment, reproduced exactly as it appears in the curriculum text:

\section{Topic: Fruit -2 hours}

- Different types of fruit

- Tastes and textures of fruit

- Where fruit comes from

- Colours and shapes of fruit

(DBE, 2011a, p.19).

The data segments were grouped according to the concept they represented and coded from $\mathrm{C} 1$ to $\mathrm{C} 18$.

2. Four Grade R learner workbooks (DBE, 2012a; DBE, 2012b; DBE, 2012c; DBE, 2012d) were issued nationally to Grade R children in 2013 by the Department of Basic Education. These workbooks are officially sanctioned Grade R resources. Selections from these texts function as supporting data sources for this study as they 1) extrapolate and elaborate the 22 primary data segment descriptions which are each limited to between two and six sentences, and 2) function as the internalising agents for the primary data segments. 
3. In order to describe the Grade R science concepts in terms of their relations to other more complex concepts taught later (AI: 3 ) the study needed to look beyond Grade R. To this end, we included two relational data sources from the current CAPS science curriculum for children between seven and twelve years old i.e. Beginning Knowledge from The National Curriculum Statement (NCS), Curriculum and Assessment Policy Statement Foundation Phase Grades R-3: English Life Skills (DBE, 2011a: pp.30-67), and The National Curriculum Statement (NCS), Curriculum and Assessment Policy Statement Intermediate Phase Grades 4-6: Natural Sciences and Technology (DBE, 2011b). The three sets of data above were selected because they are the widely available officially sanctioned texts used by teachers in public schools to teach science to most South African children.

The analytic framework

The purpose of the analysis was to establish whether text extracts representing science concepts represented these as simple scientific concepts. The analytical framework was developed as follows:

1. The conceptual framework was first translated into the following set of analytic indicators for simple scientific concepts:

AI: 1. How does the Grade R curriculum represent the defining features of a science knowledge concept with regards to:

- Its attributes

- The degree of specialisation of language

- Its relation to other concepts

- Its relation to context

AI: 2. How does the Grade R science curriculum represent the structure of a science concept with regards to the relation between content and procedural knowledge?

AI: 3. How does the Grade R curriculum represent science concepts with regards to the relation between simple and complex concepts? 
These analytic indicators needed not only to be present but also to be scientifically correct. For example, the ability to fly might be given as an attribute of a bird, but this is not an essential attribute. This analysis is premised on the idea that there are scientifically correct definitions for the phenomena studied in science. Of course, we realise that this is not strictly speaking true. At the level of scientific research, science knowledge is unsettled and constantly revised, and it is appropriate that learners should recognise this. However, school science is primarily concerned with knowledge that is - at least for the moment - settled, and agreed between scientists. For example, scientists agree that not all birds can fly, or that a triangle has three angles and three straight sides. We adapted definitions found in a science dictionary to construct simple scientific definitions of the concepts referenced in the curriculum segments. This enabled us to evaluate, by comparison, whether the descriptions of the concepts offered in the curriculum were correct.

For example:

\begin{tabular}{|l|l|}
\hline $\begin{array}{l}\text { Grade R Beginning Knowledge } \\
\text { topic }\end{array}$ & $\begin{array}{l}\text { The neo-Vygotskian notion of simple } \\
\text { scientific concept content }\end{array}$ \\
\hline $\begin{array}{c}\text { Topic: Fruit - 2 hours } \\
\text { - Different types of fruit } \\
\text { - Tastes and textures of fruit }\end{array}$ & $\begin{array}{l}\text { Fruit: In some plants the ovary of the } \\
\text { plant grows into a fruit after the flower } \\
\text { has died. Fruit usually contains the } \\
\text { seeds of the plant. Examples of fruit } \\
\text { are tomatoes, apples, avocado, pears, } \\
\text { - Where fruit comes from } \\
\text { Colours and shapes of fruit }\end{array}$ \\
(DBE, 2011a, p.19) & (Adapted from Morris, 1992, p. $\left.888^{2}\right)$ \\
\hline
\end{tabular}

The following rating scale was developed, based on the indicators identified in the analytic framework:

Although Morris (1992) is over 20 years old the content proved to be a consistent and reliable source of 'settled' scientific knowledge. The scientific definitions provided by Morris (1992) were concise and simple and therefore could be adapted for the purpose of teaching science to six-year-olds. 


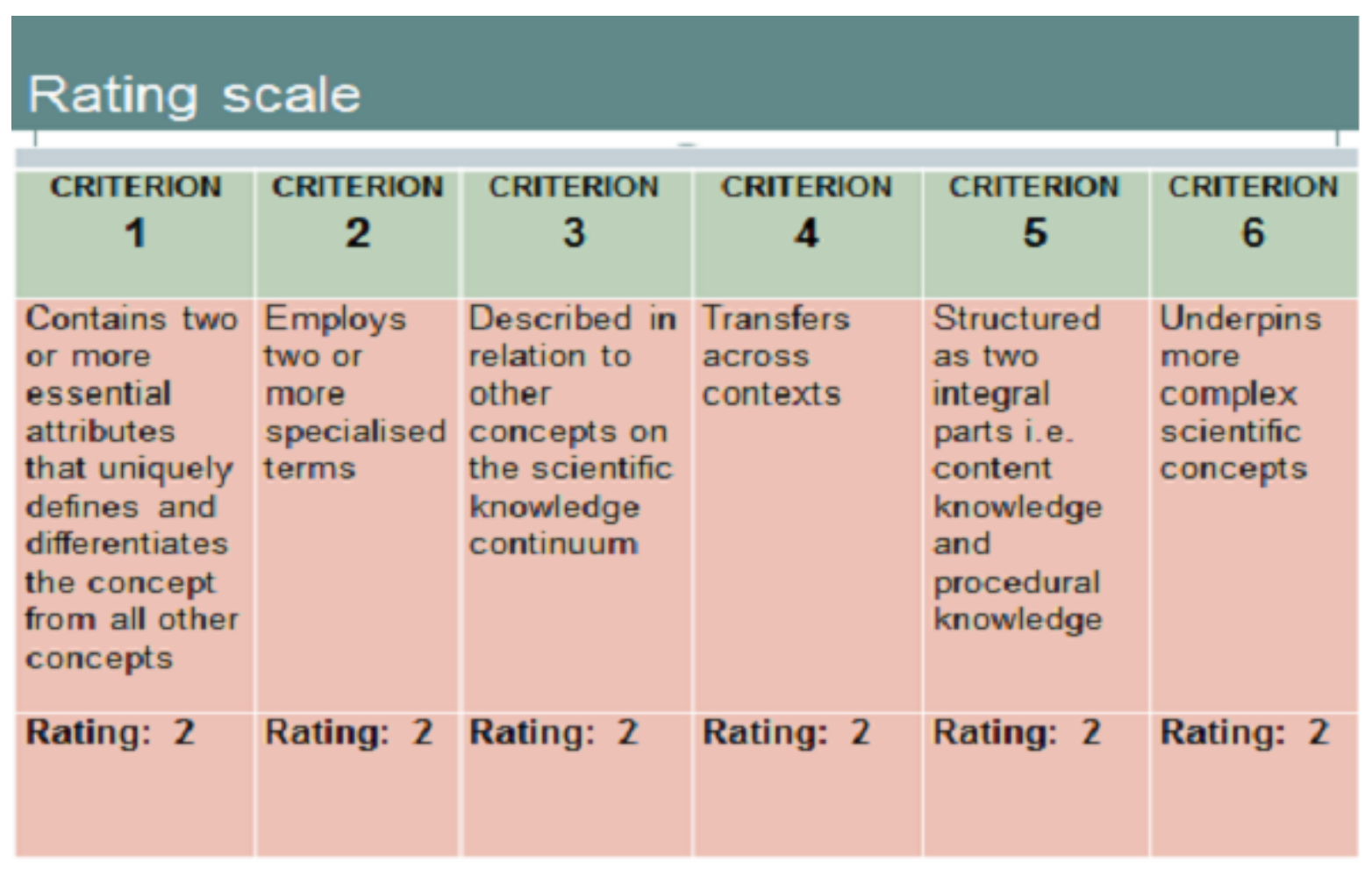

2. For purposes of comparison, the rating scale enabled us to quantify the description of each data segment. Each criterion was given a score of 2 .

- A score of $2 / 2$ indicated that the criterion is explicit and entire. A data segment that scored 12/12 was considered to represent a simple scientific concept because it met all the criteria i.e. 1) The statement included an explicit definition containing two or more essential attributes which uniquely differentiate the concept from other concepts; 2) The representation of a concept included two or more simple scientific terms; 3) There was some indication of the position of the concept in relation to other concepts on the scientific knowledge continuum; 4) Both content and procedural knowledge were referenced; 5) The representation of the concept was transferable to other contexts, and 6) the concept potentially underpins more complex scientific concepts.

- A score of $1 / 2$ indicated that the criterion was implied or partially represented in some way in the text. A data segment that scored $\geq 5 / 12$ $\leq 11 / 12$ was considered to be a potential scientific concept. The term 'potential scientific concept' is introduced in this study to refer to a concept which contains parts of, and/or infers the features of a simple scientific concept and implicitly leads the teacher towards representing 
scientific concepts. The term potential scientific concept does not pertain to Vygotsky's idea of a potential concept, although it does relate in part to Vygotsky's idea of pseudoconcept and to Hedegaard's description of an empirical ${ }^{3}$ concept. The notion of 'potential' in this context pertains to pedagogical rather than developmental potential. Realising the scientific 'potential' of a science concept rests on the likelihood of the Grade R educator interpreting and translating the partially described or implied concept into an actual simple scientific concept, in the classroom.

- A score of $0 / 2$ indicated that there was insufficient or no evidence of the six simple scientific criteria. A data segment that scored $\leq 4 / 12$ was considered to be an everyday concept: it defines an idea in terms of a person's everyday context-dependent sensory experiences and observations of the visible and obvious features of an object or phenomena. Everyday concepts are scientifically unacceptable because they are couched in everyday terms, are not transferable and do not portray the 'essence' of a concept. Everyday concepts can be erroneous e.g. a child thinks that a whale is a fish because she has observed that a whale looks like a fish and, like a fish, lives in water.

3. The three analytic indicators were each brought to bear, in turn, on each of the primary data segments $\mathrm{C} 1-\mathrm{C} 18$ (DBE, 2011a) and the supporting data in the four Grade R workbooks (DBE, 2012a; DBE, 2012b; DBE, 2012c; DBE, 2012d). Indicator A1: 3 (How does the curriculum represent the defining features of a science knowledge concept with regards to its relation to context?) was also brought to bear on the related science topics in the Grade 1-3 Foundation Phase Life Skills and the Intermediate Phase science curricula (DBE, 2011a; DBE, 2011b). A description of each of the 22 Grade R science knowledge concepts was generated. Each description was then rated according to the science concept type rating scale and benchmark criteria.

On the basis of this analysis, we categorised the data segments into the knowledge types: Simple scientific concepts, potential scientific concepts and everyday concepts. This is illustrated in the table below. Factual but within a specific context e.g. when the educator tells the class that 'In winter it
snows and people wear warm coats'. 


\begin{tabular}{|c|c|c|c|c|c|c|c|}
\hline Knowledge Type & $\begin{array}{l}\mathrm{Cr} \\
1 \\
\end{array}$ & $\begin{array}{l}\mathrm{Cr} \\
2 \\
\end{array}$ & $\begin{array}{l}\mathrm{Cr} \\
3 \\
\end{array}$ & $\begin{array}{l}\mathrm{Cr} \\
4\end{array}$ & $\begin{array}{l}\mathrm{Cr} \\
5\end{array}$ & $\begin{array}{l}\mathrm{Cr} \\
6\end{array}$ & Total \\
\hline $\begin{array}{l}\text { Simple Scientific concept } \\
\text { Fruit: In some plants the ovary of the } \\
\text { plant grows into a fruit after the flower } \\
\text { has died. Fruit usually contains the seeds } \\
\text { of the plant. Find out if something is a fruit } \\
\text { by looking for the seeds of the plant. }\end{array}$ & $2 / 2$ & $2 / 2$ & $2 / 2$ & $2 / 2$ & $2 / 2$ & $2 / 2$ & $12 / 12$ \\
\hline $\begin{array}{l}\text { Potential scientific concept } \\
\text { Fruit: grows on plants after the flower } \\
\text { dies. Fruit is eaten by humans and animals } \\
\text { because it is sweet. Take out the seeds and } \\
\text { make a fruit salad with different fruits. }\end{array}$ & $1 / 2$ & $2 / 2$ & $2 / 2$ & $0 / 2$ & $1 / 2$ & $1 / 2$ & $7 / 12$ \\
\hline $\begin{array}{l}\text { Everyday concept } \\
\text { Topic: } \text { Fruit }-2 \text { hours } \\
\text { - } \quad \text { Different types of fruit } \\
\text { - } \quad \text { Tastes and textures of fruit } \\
\text { - } \quad \text { Where fruit comes from } \\
\text { - } \quad \text { Colours and shapes of fruit } \\
\quad(\text { DBE, 2011a, p. 19) }\end{array}$ & $0 / 2$ & $1 / 2$ & $0 / 2$ & $0 / 2$ & $0 / 2$ & $0 / 2$ & $1 / 12$ \\
\hline
\end{tabular}

\section{Findings and discussion}

None of the topic statements in the data met the criteria for simple scientific concepts by scoring 12/12, as can be seen in Table 1, below, which offers an overview of the findings.

Seven of the fourteen Grade $\mathrm{R}$ topic statements were rated as potential scientific concepts $(\geq 5 / 12 \leq 11 / 12)$. These seven potential scientific concepts have some scientific features and are represented in ways that could prompt the Grade $\mathrm{R}$ educator into translating everyday representations into simple scientific terms. The following representations in the Grade R Beginning Knowledge curriculum may prompt a simple scientific definition: 1) a topic title that is unfamiliar to the Grade R learners e.g. 'Weather' (DBE, 2011a, p.17); 2) a pertinent question, e.g. 'What is a wild animal?' (DBE, 2011a, p.21);3) images of the concept in relation to the open-ended statement 'Look at the picture and talk about ...' (DBE, 2012a, pp.3, 13; DBE, 2012c, pp.3, $13,23,42$; DBE, 2012d, p.3, 33) and 4) a requirement in the workbook activities that needs to be explained to six-year-olds who cannot read. If the 
curriculum's lexicon is very simple the Grade R educator may also be prompted into sharpening the concepts into more scientific terms.

In the case of potential scientific concepts, the translation of the everyday into the scientific rests on the Grade R educator. While this is not specifically stated as an outcome in the CAPS documents, as we have mentioned, for teaching to be developmental, that is to move students to cognitively new ways of knowing, concepts cannot be left at the level of the everyday. This would lead solely to empirical rather than theoretical knowledge. For example, the topic 'Weather' in Workbook 2 (DBE, 2012b) provides images of snow. One teacher might decide to say: 'In winter, when the earth tilts away from the sun, the weather becomes colder and in some places rain becomes snow' (a simple scientific definition). Another teacher might say: 'It snows in winter'. This latter explanation is scientifically erroneous as it does not snow in winter in all geographic areas.

Educators' responses cannot be easily predicted. In the absence of explicit scientific definitions and related scientific procedures in the Grade $\mathrm{R}$ curriculum, the educator is likely to translate the Grade $\mathrm{R}$ science curriculum representations according to her own science knowledge, her understanding of a six-year-old's competencies and her approach to early science education. In South Africa, very few Grade R educators are graduates or pre-primary specialists (Umalusi et al, 2010). The majority have an eighteen month part-time Level 4 or 5 Certificate in Early Childhood Education (ECD) and have been drawn from the field of educare where the focus is on health, safety and the child's emotional and social well-being. This would suggest that it is unlikely that most Grade R teachers would have the level of science knowledge or of science pedagogy that would enable them to translate potential simple scientific concepts into actual simple scientific concepts. Instead, there is a real danger that teachers would most often represent these topics in everyday knowledge terms. Furthermore, in the South African context, well-resourced schools that serve advantaged communities are more likely to have well-trained specialist teachers than schools in poorer areas. This is likely to exacerbate existing class based inequalities in epistemological access.

Furthermore, the Grades 1, 2 and 3 science subject area Beginning Knowledge is structured in a similar way to the Grade R science curriculum. This suggests that there is a strong possibility that the problems described here, in relation to the Grade R curriculum, would also apply to the whole Foundation 
Phase curriculum. If the acquisition of simple scientific knowledge begins only in Grade 4 it is understandable that South African school children score poorly on international rating scales (TIMSS, 2011) and that there is a dearth of Grade 12 maths and science learners (DBE, 2011d).

\section{Everyday concepts}

Seven of the fourteen Grade R science concepts presented in the curriculum were categorised as everyday concepts $(>4 / 12)$, on the grounds that the description of the concept was not only incomplete with regard to key features of a simple scientific concept but also scientifically inaccurate. This means that teachers are not guided by the curriculum towards a pedagogy that potentially realises these as simple scientific concepts. Instead, with regard to these topics, the curriculum texts guide teachers of most six-year-olds in South Africa towards representing science in terms of everyday concepts.

This finding gives grounds for considerable concern. Learning scientific knowledge is developmental in that young children develop cognitive competencies and learn about abstraction through the process of acquiring simple scientific knowledge (Fleer, 2010; Davydov, 1990, 2008; Hedegaard, 2002). In other words, in the absence of the teaching and learning of simple scientific concepts young children are unlikely to acquire the knowledge and skills necessary for formal schooling. While CAPS documents focus on students learning through experiential engagement with concepts, we would argue that this leaves the engagement solely at the level of everyday concepts, leading to empirical knowledge. We argue, therefore, that CAPS is limited in its focus on children learning experientially solely through play and exploration. The kind of knowledge acquired in this way can be very problematic. An example illustrates our argument: a whale, fish and shark all swim in the ocean. Therefore, empirically, a whale is of the same species as a fish or shark. A cow bears no resemblance to a whale and therefore is completely different to a whale, empirically. Of course, a whale and a cow are mammals, whereas a fish and a shark are not. If one learns only through empirical everyday experiences, the knowledge gained can very often be incorrect. The lack of dialectical logic underpinning CAPS is, therefore, problematic. For optimal teaching scientific and everyday concepts need to be linked so that children can develop cognitively. 
As has been mentioned above, there is considerable research support for the claims that six year old children can and should learn to think abstractly (Winkler-Rhoades, Carey, and Spelke, 2013, Haynes. and Murris, 2012; Fleer, 2010; Ginsberg and Golbeck, 2004; Egan, 2002); that learning scientific concepts is an important vehicle for teaching abstract thought (Sylva, et al., 2004) and that a limited exposure to science in the early years and less than ideal pedagogical practices can create barriers to the later learning of science (Mantzicopoulos, et al., 2008). This would suggest that offering learners the opportunity to learn scientific concepts is part of a quality early education, and it is widely accepted that children who have had a quality preschool education are significantly advantaged in adulthood (Schweinhart, 2003).

\begin{tabular}{|c|c|c|}
\hline $\begin{array}{l}\text { Grade R science topic } \\
\text { concepts }\end{array}$ & $\begin{array}{c}\text { Rating } \\
\text { benchmarks }\end{array}$ & $\begin{array}{c}\text { Type of science concepts for } \\
\text { six-year-olds }\end{array}$ \\
\hline $\begin{array}{l}-\quad \text { The human body }(\mathrm{C} 1, \\
\quad \text { C1.1, C1.2, C1.3, C1.4)) } \\
-\quad \text { Colour }(\mathrm{C} 3) \\
-\quad \text { Weather }(\mathrm{C} 4) \\
-\quad \text { Birds }(\mathrm{C} 13) \\
-\quad \text { Reptiles }(\mathrm{C} 13, \mathrm{C} 14) \\
-\quad \text { Time }(\mathrm{C} 17)\end{array}$ & $\geq 5 / 12 \leq 11 / 12$ & $\begin{array}{l}\text { Potential scientific concepts } \\
\text { Each concept representation contains } \\
\text { sufficient but not all of the features of a } \\
\text { simple scientific concept. Although there may } \\
\text { be some omissions and scientific countering, } \\
\text { the representations may prompt the Grade R } \\
\text { educator to translate an everyday concept into } \\
\text { a simple scientific concept. }\end{array}$ \\
\hline $\begin{aligned}- & \text { Shape }(\mathrm{C} 3) \\
- & \text { Fruit }(\mathrm{C} 8) \\
- & \text { Vegetables }(\mathrm{C} 9) \\
- & \text { Water }(\mathrm{C} 7) \\
- & \text { Domesticated animals } \\
& (\mathrm{C} 10, \mathrm{C} 11) \\
- & \text { Seasons as in Summer, } \\
& \text { Autumn, Winter and } \\
& \text { Spring }(\mathrm{C} 2, \mathrm{C} 5, \mathrm{C} 6, \mathrm{C} 12) \\
- & \text { Wild animals }(\mathrm{C} 16)\end{aligned}$ & $\leq 4 / 12$ & $\begin{array}{l}\text { A type of factual but context-dependent } \\
\text { concept. This representation does not point } \\
\text { the teacher towards pedagogic... }\end{array}$ \\
\hline $\begin{array}{l}\text { (No segments met these } \\
\text { criteria) }\end{array}$ & $12 / 12$ & Simple scientific concepts \\
\hline
\end{tabular}

While table 1 provides an overview of the findings, we elaborate how we arrive at these findings by animating an example from the research below in relation to the knowledge concepts 'domesticated animals': 
The following two Grade R curriculum topics, 'Dairy farming' (C10) and 'Wool farming' (C11) represent the concept 'domesticated animals':

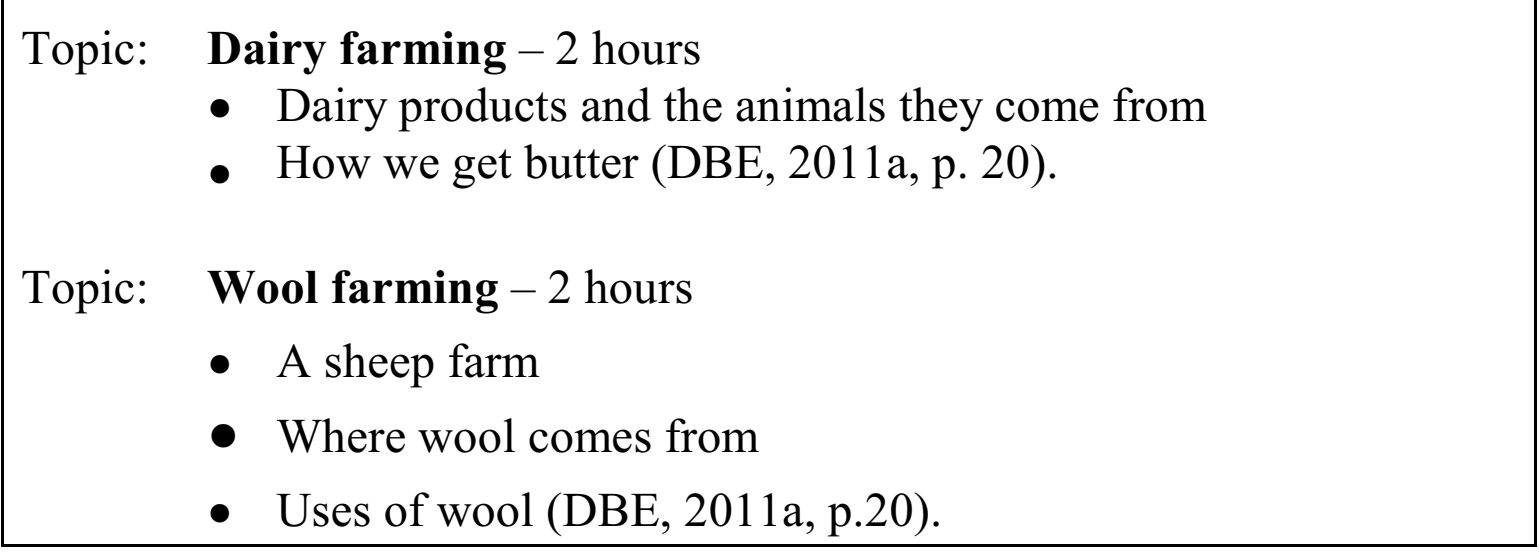

These topics and the related supporting activities (DBE, 2012c) were analysed according to the following scientific definitions. The first definition is how scientists think about domesticated animals and is represented in a science dictionary (Morris, 1992); the second is a simple scientific definition for six-year-olds created from the dictionary definition for the purpose of analysing the Grade R science curriculum's representation of domesticated animals:

Domesticated: Biology. to control or adapt an animal or plant for human use or life with humans (Morris, 1992, p.671).

Domesticated: Animals that humans keep and live with because they are helpful to us in some way (based on and adapted from Morris, 1992, p.671).

The essence of domesticated (and, its counterpart, wild) is that it pertains to the human perspective e.g. we consider crocodiles who roam freely in the Kruger Park as wild but, when crocodiles are farmed for their hide, the crocodile has become domesticated in terms of human use. Domesticated animals, as in the topics above, pertain to a particular context i.e. the agricultural. Pets are also domesticated animals but the context differs.

1. How does the Grade R curriculum describe the defining features of the concept domestic animals as represented by the curriculum topics 'Dairy farming' (C10) and 'Wool farming' (C11) with regards to:

- Its attributes 
The concept, domesticated animals, which is inferred in the topics 'Dairy farming' and 'Wool farming', is made more explicit in Workbook 3's 'Farm animals' (DBE, 2012c, pp.22-25). The two page introduction depicts images of humans engaging with farm animals for their own use e.g. milking a cow, collecting eggs and honey from hens and bees, and shearing a sheep for its wool (DBE, 2012c, pp.22-23). The open-ended question, 'Look at the picture and talk about what you see' (DBE, 2012c, p. 23), in conjunction with these explicit images, is likely to prompt discussions on animal domestication in the farming context. The matching activity that follows refers to one of the essential attributes of domestication i.e. 'Draw a line to show what we get from these animals' (my italics, DBE, 2012c, p.24). Teaching six-year-olds the song 'Old MacDonald' (DBE, 2012c, p.25), supports, in part, the concept of domesticated animals by naming the animals.

Two factors counter the Grade R science curriculum's representation of the concept domesticated animals. Firstly, in the absence of a simple scientific definition of domesticated animals in the curriculum, it rests on the Grade $\mathrm{R}$ educator to: 1) identify the underlying concept underpinning the topics 'Dairy farming' and 'Wool farming' and 2) determine the essential features unique to the concept. Secondly, the Grade R science curriculum confines domesticated animals to one particular context i.e. farming. These two factors are likely to result in conceptual differentiation. In other words: one Grade R educator may represent domesticated animals as an everyday concept by taking the topics and related workbook activities at face value e.g. matching the image of a hen to an image of an egg, but another Grade $\mathrm{R}$ educator may be prompted to 1) provide a simple scientific definition containing the attributes that are unique to domesticated animals, and 2) ask questions that lift out the essential attributes contained in the definition and apply them to another context e.g. 'Why do we keep dogs?' and 'Are the crocodiles at a crocodile farm domesticated or wild? Why?' In conclusion: the Grade R science curriculum's partially represents the concept domesticated animals in terms of essential attributes.

- The degree of specialisation of language

The Grade R curriculum employs the context specific terms 'Dairy farming', 'Wool farming' (DBE, 2011a, p.20) and 'Farm animals' (DBE, 2012c, pp.22-31) in place of the more scientifically appropriate 'domesticated animals'. If the curriculum introduces the topic concept 'Wild animals' (DBE, $2011 \mathrm{a}, \mathrm{p} .21$ ), the notion of opposites indicates the logical inclusion of its 
conceptual counterpart i.e. 'Domesticated animals'. In conclusion: the Grade $\mathrm{R}$ science curriculum represents domesticated animals in everyday terms.

- Relation of topic concept to other concepts

In terms of grouping the Grade R science curriculum introduces the topics 'Wool Farming' and 'Dairy farming' (DBE, 2011a, p.20) in relation to one another in Term 3. In terms of co-location domesticated animals is isolated from its conceptual counterpart 'Wild animals' and 'Find out about one wild animal' (DBE, 2011a, p.21) which is positioned at the end of Term 4. In terms of sequence the two related topic concepts domestic and wild are illogically separated by the topic concepts 'Healthy Environment', Spring', 'Birds', 'Reptiles' and 'Dinosaurs' (DBE, 2011a, pp.20, 21). In Workbook 3 'Sea animals' (DBE, 2012c, pp.32-41), which features wild and domesticated animals, is logically positioned after 'On the farm' (DBE, 2012c, pp.22-31) but, counter to the notion of sequence in terms of progression, precedes the introduction of 'Wild animals' (DBE, 2012c, pp.42-53). In conclusion: the concept domesticated animals is a stand-alone concept in terms of its relations to other concepts.

- Relation of topic concept representation to context

In the absence of the term 'domesticated animal' or its equivalent the Grade $\mathrm{R}$ science curriculum's representation of the concept domesticated animals is not transferable.

In conclusion: The Grade R science curriculum's representation of farmed animals pertains, in part, to the neo-Vygotskian notion of content knowledge ${ }^{4}$ because the workbook images and text have the potential to prompt the educator into defining domesticated animals, in part, in terms of essential attributes.

2. How does the Grade R science curriculum describe the structure of the science knowledge concept domesticated animals with regards to the relation between content and procedural knowledge?

Having established above that the curriculum relates, in part, to content knowledge, this section considers the related curriculum activities in terms of 
procedural knowledge. The Grade $\mathrm{R}$ science curriculum provides one internalising activity i.e. a simple one-to-one matching activity (DBE, 2012c, p.24) which places farm animals in relation to their produce. This activity pertains to the internalisation of domesticated animals by 'operating' with the concept but is unlikely to operate according to the law of equivalence i.e. the activity is too simple and therefore familiar to most six-year-olds. In conclusion: the Grade R science curriculum represents, in part, the concept domesticated animals as procedural and content knowledge.

3. How does the Grade R curriculum describe the science knowledge concept domesticated animals with regards to the relation between simple and complex concepts?

The Grade $\mathrm{R}$ representation of domesticated animals potentially underpins one other more complex school science concept. Domesticated animals in the farming context in Grade R, is extended to another context i.e. 'Pets' in Grade 1 as in 'How to look after pets at home - include shelters, food water, animal cleanliness. . . giving exercise. . ' (DBE, 2011a, p.32). 'Pets' is, however, positioned in isolation without any references to domesticated animals in the farming context.

The following topic concepts counter the notion of domesticated animals in Grade R underpinning more complex concepts in later grades:

- The Grade 2 topic 'Animals' (DBE, 2011a, p.43), which describes the simple division of 'Animals' into 'Farm animals' and 'Wild animals', precedes the more complex Grade R topic concepts 'Wool Farming' and 'Dairy farming' (DBE, 2011a, p.21) and 'Wild animals' and 'find out about one wild animal' (DBE, 2011a, p.21).

- The Grade 3 topic 'Animals and creatures that help us' is underpinned, in part, by Grade $\mathrm{R}$ understanding of animal domestication but it also reiterates Grade R content (DBE, 2012c, pp.22-24) by stating 'Animals that give us food and/or clothes - bees - chickens - cows - sheep' (DBE, 2011a, p.57).

- The simple scientific concept that 'All animals depend on green plants for food: energy' (DBE, 2011b, p.39) is introduced in Grade 4 whereas the more complex idea of mankind's dependency on and use of farm animals 
as a source of energy is positioned in Grade R (DBE, 2011a, p.20; DBE, 2012a, pp.22-24).

- The concept domesticated animals does not feature in the Intermediate science curriculum (DBE, 2011b).

In conclusion: the Grade R's representation of domesticated animals does not underpin more complex science concepts.

After bringing the three analytic indicators to bear on the Grade $\mathrm{R}$ topics 'Dairy farming' (C10) and 'Wool farming' (C11) related internalising activities (DBE, 2012c), the conclusion was that the Grade R science curriculum represents the topic concept domesticated animals as an empirical concept i.e. a type of everyday concept that is factually correct within a particular context. The reasons are as follows:

- The Grade R science curriculum insufficiently represents $(\leq 4 / 12)$ domesticated animal in terms of the six key features of a simple scientific concept

- The Grade $\mathrm{R}$ representation of domesticated animal is unlikely to prompt the Grade $\mathrm{R}$ educator into translating the curriculum representations in terms of a simple scientific concept.

Table 2: Rating for the Grade $\mathbf{R}$ science curriculum representation of domesticated animals.

\begin{tabular}{|c|c|c|c|c|c|}
\hline \multicolumn{6}{|c|}{ Criteria Description and Rating Scale } \\
\hline Criterion 1 & Criterion 2 & Criterion 3 & Criterion 4 & Criterion 5 & Criterion 6 \\
\hline $\begin{array}{l}\text { Exploys two } \\
\text { or more } \\
\text { essential } \\
\text { attributes. . . }\end{array}$ & $\begin{array}{l}\text { Contains two } \\
\text { or more } \\
\text { specialised } \\
\text { terms }\end{array}$ & $\begin{array}{l}\ldots \text { in } \\
\text { relation to } \\
\text { other } \\
\text { concepts }\end{array}$ & $\begin{array}{l}\ldots \\
\text { transferable } \\
\text { across } \\
\text { contexts }\end{array}$ & $\begin{array}{l}\text {.. .two } \\
\text { integral parts } \\
\text { i.e. content } \\
\text { and } \\
\text { procedural } \\
\text { knowledge }\end{array}$ & $\begin{array}{l}\text { Underpins } \\
\text { more } \\
\text { complex } \\
\text { scientific } \\
\text { concepts }\end{array}$ \\
\hline $1 / 2$ & $0 / 2$ & $0 / 2$ & $0 / 2$ & $1 / 2$ & $0 / 2$ \\
\hline
\end{tabular}




\section{Conclusion}

This study set out to examine the extent to which the most widely available Grade R curriculum documents made simple scientific concepts available to learners. We found that these texts contain no explicit elaboration of scientific concepts. Half the topics contained in the documents were coded as 'potential' scientific concepts, leaving it up to teachers to realise these descriptions as scientific concepts. Unfortunately, the qualifications profile of preschool teachers leads us to question whether they would be likely to do so.

The other half of the topic statements were coded as everyday concepts. While accessing learners' spontaneous, or everyday, concepts is part of the pedagogic process, no real science learning takes place if learners' everyday understandings are not revised in the acquisition of - initially simple scientific concepts. In effect, the curriculum's everyday representations of science steer the educator away from the idea that the science knowledge that is taught in schools should ideally relate more closely to the scientists' notion of science (Larkin, 2013; Ramnarain, 2010; Sharma and Anderson, 2009; Davydov, 2008; Hedegaard, 2002). We have noted that CAPS expressly does not require the elaboration of scientific concepts and in fact promotes experiential learning of concepts through play and exploration. We have argued that this is problematic as it rests on the binary logic that assumes everyday and scientific concepts are two separate things, rather than two dialectically related concepts that are required for cognitive development. Relying on experiential learning of concepts can, we have argued, lead to serious misunderstandings for the developing child who is relying on the construction of empirical, rather than theoretical knowledge.

Van der Berg (2014) has shown that expanded preschool education has not thus far substantially advantaged South African learners, particularly poorer learners. He argues that the reason for this is the poor quality of much of this education. We believe that the way in which the current curriculum specifies science content at Grade R level contributes to this poor quality and to this inequality. 


\section{References}

Bodrova, E. and Leong, D.J. 2001. Tools of the mind: a case study of implementing the Vygotskian approach in American early childhood and primary classrooms. Geneva: International Bureau of Education.

Davydov, V. 1990. Soviet studies in mathematics education: volume 2. Types of generalizsations in instruction: logical and psychological problem in the structuring of school curricula. Reston, Virginia: The National Council of Teachers of Mathematics.

Davydov, V. 2008. Problems of developmental instruction: a theoretical and experimental psychological study. New York: NovaScience Publishers Inc.

Department of Basic Education. 2011a. National Curriculum Statement (NCS), Curriculum and Assessment Policy Statement Foundation Phase Grades R-3: English Life Skills. Available http://www.education.gov.za/LinkClick.aspx?fileticket=PCBnG0tzI14\%3D\&t $\underline{\mathrm{abid}=571 \& \mathrm{mid}=1563}$ [11 April, 2016]

Department of Basic Education. 2011b. National Curriculum Statement (NCS), Curriculum and Assessment Policy Statement Intermediate Phase Grades 4-6: Natural Sciences and Technology http://www.education.gov.za/LinkClick.aspx?fileticket=IzbFrpzoQ44= [11 April 2016]

Department of Basic Education. 2011d. Report on the National Senior Certificate Examination 2011: Technical report. Available www.education.gov.za [2013, January 1].

Department of Basic Education. 2012a. Grade R workbook 1. Pretoria:

Department of Basic Education. Available http://www.education.gov.za [2013, June]

Department of Basic Education. 2012b. Grade R workbook 2. Department of Basic Education. Available http://www.education.gov.za [2013, June]. 
Department of Basic Education. 2012c. Grade R workbook 3. Pretoria: Department of Basic Education. Available http://www.education.gov.za [2013, June].

Department of Basic Education. 2012d. Grade R workbook 4. Pretoria: Department of Basic Education. Available http://www.education.gov.za [2013, June].

Department of Basic Education. 2012e. Report on the Annual National Assessments, 2012.Grades 1-6 and 9. Available http://www.education.gov.za [2013, January 1].

Doris, E. 1991. Doing what scientists do: children learn to investigate their world. Portsmouth, New Hampshire: Heinemann.

Egan, K. 2002. Getting it wrong from the beginning: our progressive inheritance from Herbert Spencer, John Dewey, and Jean Piaget. New Haven: Yale University Press.

Fleer, M. 2010. Early learning and development: cultural-historical concepts in play. New York: Cambridge University Press.

French, L. 2004. Science as the center of a coherent, integrated early childhood curriculum. Early Childhood Research Quarterly, 19: pp.138-149.

Gelman, R. and Brenneman, K. 2004. Science learning pathways for young children. Early Childhood Research Quarterly, 19(1): pp.150-158.

Ginsberg, P. and Golbeck, S.L. 2004. Thoughts on the future of research on mathematics and science learning and education. Early Childhood Research Quarterly, 19(1): pp.190-200.

Harrison, G. 2011. Mediating self-regulation in a kindergarten class in South Africa: an exploratory case study. MEd. Thesis, University of Cape Town

Haynes, J. and Murris, K. 2012. Picturebook, pedagogy and philosophy. New York: Routledge.

Hedegaard, M. 2002. Learning and child development: a cultural-historical study. Aarhus, Denmark: Aarhus University Press. 
High/Scope Perry Preschool Study. 2005. Lifetime effects: the High/Scope Perry preschool study through age 40. Available www.highscope.org [2010 May 2].

Klinck, K. 2013. Education for unsuccessful school leavers in South Africa - a proposal to prevent exclusion of the majority of South Africa's learners from Further Education and Training. Presentation at 2nd National Qualifications Framework (NQF) research conference: Building articulation and integration. 4th-6th March 2013 http://www.saqa.org.za/docs/pres/2013/klinck_k.pdf [11 April, 2016]

Larkin, D. B. 2013. Deep knowledge: learning to teach science for understanding and equity.New York: Teachers College Press.

Lind, K. 1998. Science in early childhood: developing and acquiring fundamental concepts and skills. The Forum on Early Childhood Science, Mathematics, and Technology Education. Washington DC. February 6-8. Available http://www.eric.ed.gov/PDFS/ED418777.pdf [2013, January].

Luria, A.R. 1976. Cognitive development; its cultural and social foundations. Cambridge, Massachusetts: Harvard University Press.

Mantzicopoulos, P., Patrick, H. and Samarapungavan, A. 2008. Young children's motivational beliefs about learning science. Early Childhood Research Quarterly, 23: pp.378-394.

Morais, A., Neves, I. and Pires, D. 2004. The what and the how of teaching and learning: going deeper into sociological analysis and intervention. In Muller, J., Davies, B. and Morais, A. (Eds), Thinking with Bernstein, working with Bernstein. London: Routledge, pp.42-50.

Morris, C.G. (Ed.) 1992. Academic press dictionary of science and technology. San Diego, California: Academic Press, Inc.

Ramnarain, U. (Ed.) 2010. Teaching scientific investigations. Gauteng, South Africa: Macmillan South Africa (Pty) Ltd.

Rogoff, B. 1990. Apprenticeship in thinking, cognitive development in social context. New York: Oxford University Press. 
Schweinhart, L.J. 2003. Benefits, costs and explanations of the high/scope Perry Preschool Program. The 2003 Biennial Meeting of the Society for Research in Child Development. Tampa. April 24-27.

Sharma, A. and Anderson, C.W. 2009. Recontextualization of science from lab to school: implications for science literacy. Science and Education, 18 (9): pp.1253-1275.

Skamp, K. (Ed.) 1998. Teaching primary science constructively. Australia: Harcourt Brace \& Company.

Shonkoff, J.P. and Phillips, D.A. (Eds). 2000. From neurons to neighbourhoods: the science of early childhood development. Washington, DC, USA: National Academies Press. Available http://site.ebrary.com/lib/columbia/Doc?id=10038720\&ppg=76 [2013, November, 20].

Sylva, K., Melhuish, E., Sammons, P., Siraj-Blatchford, I. and Taggart, B. 2004. The effective provision of pre-school education (EPPE) project: final report. A longitudinal study funded by the DfES 1997-2004. London: Institute of Education, University of London.

Trends in International Mathematics and Science Studies (TIMSS). 2011. Available timss.bc.edu/timss2011

Umalusi Council for Quality Assurance in General and Further Education and Training (South Africa), Centre for Education Policy Development (Johannesburg, South Africa), University of the Witwatersrand. School of Education (2010) Will Grade ' $R$ ' really improve the quality of South African education? Improving public schooling seminars. Johannesburg: CEPD.

Van der Berg, S. 2014. The impact of the introduction of grade $R$ on learning outcomes. Report commissioned by the Department of Performance Monitoring and Evaluation (DPME) in the Presidency in partnership with the Department of Basic Education (DBE) http://resep.sun.ac.za/wp-content/uploads/2014/06/Grade-R-Evaluation-1-3-2 5-Final-Unpublished-Report-13-06-17.pdf [11 April, 2016] 
Vygotsky, L. 1962. Thought and language. Hanfinann, E. and Vakker, G. (Eds). Cambridge, Massachusetts: The Massachusetts Institute of Technology Press.

Vygotsky, L. 1978. Mind in society. Cole, M., John-Steiner, V., Scribner, S. and Souberman, E. (Eds). Cambridge, England: Harvard University Press.

Winkler-Rhoades, N., Carey, S.C. and Spelke, E.S. 2013. Two-year-old children interpret abstract, purely geometric maps. Developmental Science, 16(3): pp.365-376. Available www.wjh.harvard.edu.

Zaporozhets, A.V. and Elkonin, D.B. (Eds). 1971. The psychology of preschool children. Cambridge, Massachusetts: The MIT Press.

Anya Morris

Joanne Hardman

Heather Jacklin

School of Education

University of Cape Town

anyamorris@absamail.co.za

joanne.hardman@uct.ac.za

heather.jacklin@uct.ac.za 